\title{
Modeling secondary organic aerosol in an urban area: application to Paris, France
}

\author{
F. Couvidat ${ }^{1}$, Y. Kim ${ }^{1}$, K. Sartelet ${ }^{1}$, C. Seigneur ${ }^{1}$, N. Marchand ${ }^{2,3}$, and J. Sciare ${ }^{4}$ \\ ${ }^{1}$ CEREA, Joint Laboratory École des Ponts ParisTech/EDF R\&D, Université Paris-Est, 77455 Marne-la-Vallée, France \\ ${ }^{2}$ Aix-Marseille Université, Laboratoire Chimie Environnement, 13331, Marseille cedex 03, France \\ ${ }^{3}$ CNRS, FRE 3416, 13331, Marseille cedex 03, France \\ ${ }^{4}$ LSCE, CNRS-CEA-UVSQ, Gif-sur-Yvette, France
}

Correspondence to: F. Couvidat (couvidaf@cerea.enpc.fr)

Received: 1 August 2012 - Published in Atmos. Chem. Phys. Discuss.: 10 September 2012

Revised: 5 December 2012 - Accepted: 3 January 2013 - Published: 23 January 2013

\begin{abstract}
A secondary organic aerosol (SOA) model, $\mathrm{H}^{2} \mathrm{O}$ (Hydrophilic/Hydrophobic Organic), is evaluated over the Paris area. This model treats the formation of SOA with two kinds of surrogate species: hydrophilic species (which condense preferentially on an aqueous phase) and hydrophobic species (which condense only on an organic phase). These surrogates species are formed from the oxidation in the atmosphere of volatile organic compounds (VOC) by radicals (HO and $\mathrm{NO}_{3}$ ) and ozone. These VOC are either biogenic (isoprene, monoterpenes and sesquiterpenes) or anthropogenic (mainly aromatic compounds). This model includes the formation of aerosols from different precursors (biogenic precursors, aromatics), and semi-volatile organic compounds (SVOC) from traffic. The $\mathrm{H}^{2} \mathrm{O}$ aerosol model was incorporated into the Polyphemus air quality modeling platform and applied to the Paris area and evaluated by comparison to measurements performed during the Megapoli campaign in July 2009.
\end{abstract}

The comparison to measurements in the suburbs and in the city center of Paris shows that the model gives satisfactory results for both elemental carbon (EC) and organic carbon (OC). However, the model gives a peak of OC concentrations in the morning due to high emissions from traffic, which does not appear in measurements. Uncertainties in the modeled temperature, which can affect the gas-particle partitioning, in the partitioning of primary SVOC or underestimation of primary organic aerosol (POA) evaporation by the model could explain the differences between model and measurements. Moreover, using a theoretical mechanism for the oxidation of primary SVOC and intermediate volatility organic com- pounds (IVOC), POA concentrations were found to be likely overestimated by models due to the use of simple partitioning constants (which do not take into account the affinity of a compound with the liquid aerosol solution) or due to the assumption that the organic aerosol solution is a one-phase ideal solution. The organic aerosol in the city center of Paris was found to be originating mostly from distant sources with only 30 to $38 \%$ due to local sources.

\section{Introduction}

Fine particulate matter (PM) with an aerodynamic diameter inferior to $2.5 \mu \mathrm{m}\left(\mathrm{PM}_{2.5}\right)$ is regulated because of its impact on human health, in particular, in urban areas with a high traffic density. Furthermore, $\mathrm{PM}_{2.5}$ degrades atmospheric visibility and influences climate change. Organic aerosol concentrations are difficult to represent in three-dimensional (3D) air quality models, which estimate $\mathrm{PM}_{2.5}$ formation, due to the complexity of phenomena involved (gas and particle phase chemistry, oligomerization, hygroscopicity, nonideality of particles) and to the large number of organic species involved originating from diverse sources (anthropogenic and biogenic). A large fraction of PM emissions from traffic is organic and, therefore, could contribute significantly to organic $\mathrm{PM}_{2.5}$ in urban areas. As 19 of the 20 largest European cities exceed the World Health Organization Air Quality Guideline (10 $\mathrm{g} \mathrm{m}^{-3}$ annual mean), efforts have to be made to understand organic aerosol formation in urban areas and to represent organic matter (OM) as accurately as 
possible in air quality models that are used for the design of emission control strategies. Organic PM is either primary (directly emitted as particles) or secondary (formed in the atmosphere by the formation of low-volatility compounds by chemical reaction). Both primary organic aerosols (POA) and secondary organic aerosols (SOA) are currently poorly understood (Kanakidou et al., 2005; Carlton et al., 2009; Jimenez et al., 2009).

Organic aerosol formation in an urban area has been studied in numerous studies over US cities (e.g., Griffin et al., 2002; Russell and Allen, 2005; Vutukuru et al., 2006; Murphy and Pandis, 2009) and over Mexico City during the MILAGRO project (e.g., Dzepina et al., 2011; Hodzic et al., 2010; Tsimpidi et al., 2011; Shrivastava et al., 2011). However, the modeling of organic aerosols in a European urban megacity has not been extensively studied yet, although some comparisons of model simulations to measurements have been reported (Sciare et al., 2010).

In this work, a model based on the molecular surrogate approach is used to simulate organic aerosols in the Paris area: the Hydrophilic/Hydrophobic Organic $\left(\mathrm{H}^{2} \mathrm{O}\right)$ model (Couvidat et al., 2012). The molecular surrogate approach (Pun et al., 2002, 2006) consists in associating experimental data with several molecular structures, which are surrogates of a large number of SOA species, to extrapolate SOA formation from smog chambers to the atmosphere. In the molecular surrogate approach, several properties, which are typically not taken into account in empirical approaches, can be readily estimated (e.g., condensation on an aqueous phase, oligomerization, hygroscopicity, non-ideality) and treated explicitly in the model. This model includes primary semi-volatile organic compounds (SVOC), oxidation of several precursors (aromatics, isoprene, monoterpenes, sesquiterpenes) under various conditions (oxidation by $\mathrm{HO}$ under high- $\mathrm{NO}_{\mathrm{x}}$ and low- $\mathrm{NO}_{\mathrm{x}}$ conditions, oxidation by $\mathrm{O}_{3}$ and by $\mathrm{NO}_{3}$ ) and processes (condensation on an organic phase or an aqueous phase, oligomerization, hygroscopicity, and non-ideality).

The $\mathrm{H}^{2} \mathrm{O}$ organic model has already been implemented in the Polyphemus air quality platform (Mallet et al., 2007) and evaluated over Europe from June 2002 to July 2003 (Couvidat et al., 2012). This evaluation showed that, even if $\mathrm{H}^{2} \mathrm{O}$ tends to underestimate organic carbon (OC) concentrations, it gives satisfactory results as the model performance criteria proposed by Boylan and Russell (2006) are met for OC concentrations and as it almost achieves the model goal criteria. However, the model has not been evaluated at the scale of a city and the performance of the model over on urban area with fresh emissions from traffic is unknown. Therefore, we present here a model performance evaluation over a megacity: organic aerosols are simulated over the Paris area during July 2009 and are compared to the results of the Megapoli (Megacities: emissions, urban, regional and Global Atmospheric POLlution and climate effects, and Integrated tools for assessment and mitigation) campaign. The origins of organic aerosols in Paris and the effect of a detailed treatment of primary organic aerosols on modeled concentrations are also investigated.

\section{Model presentation}

The Polair3D air quality model (Sartelet et al., 2007) of the Polyphemus air quality platform (Mallet et al., 2007) is used to simulate air quality over the Paris area. It is used with the Carbon Bond 05 model (CB05) (Sarwar et al., 2008) for the gas phase chemistry, ISORROPIA (Nenes et al., 1998) for the formation of inorganic aerosol, the SIze REsolved Aerosol Model (SIREAM) (Debry et al., 2007) for simulating the dynamics of the aerosol size distribution, and the $\mathrm{H}^{2} \mathrm{O}$ model for SOA formation (Couvidat et al., 2012). RACM is modified to take into account the reactions described by Couvidat et al. (2012).

$\mathrm{H}^{2} \mathrm{O}$ is based on the AER/EPRI/Caltech (AEC) model (Pun et al., 2002, 2003, 2006; Kim et al., 2011), which has already been used by Royer et al. (2011) to simulate particle concentrations. It distinguishes two kinds of surrogate SOA species: hydrophilic species (which condense mainly on an aqueous phase) and hydrophobic species (which condense only on an organic phase due to their low affinity with water). Hydrophilic species may also condense on an organic phase in the absence of aqueous particles, i.e., at very low relative humidities. Distinction between hydrophobic and hydrophilic compounds is based on their octanol/water coefficient (Pun et al., 2006) or their partitioning between the organic and aqueous phases (Couvidat and Seigneur, 2011). However, aqueous-phase chemistry, which could lead to significant amount of SOA (Ervens et al., 2011), is not taken into account in this study and will be the object of future studies.

Two approaches are used in this study to treat primary SVOC and their oxidation products. The first approach called " $\mathrm{H}^{2} \mathrm{O}-\mathrm{Ref}$ " uses the parameterization of Couvidat et al. (2012) for primary and aged organic species. In this parameterization, POA are treated as SVOC. Their concentrations in the particle phase depend on the amount of OM on which SVOC will partition and on temperature (which influences the volatility of compounds). SVOC emissions are estimated from POA emissions by using a SVOC/POA factor of 5 (Couvidat et al., 2012). Then, SVOC are distributed among three compounds: POAIP, POAmP and POAhP representing respectively $25 \%, 32 \%$ and $43 \%$ of SVOC, with partitioning constants (inverse of the saturation concentrations $C *$ defined by Donahue et al., 2006) of $1.1 \mathrm{~m}^{3} \mu \mathrm{g}^{-1}$, $0.0116 \mathrm{~m}^{3}{\mu \mathrm{g}^{-1}}^{-1}$ and $0.00031 \mathrm{~m}^{3} \mu \mathrm{g}^{-1}$, respectively. Moreover, SVOC in the gas phase can be oxidized and form less volatile compounds. The aging of primary SVOC is taken into account with the following three reactions:

$\mathrm{POAlP}+\mathrm{HO} \stackrel{k}{\rightarrow}$ SOAlP

$\mathrm{POAmP}+\mathrm{HO} \stackrel{k}{\rightarrow} \mathrm{SOAmP}$ 
$\mathrm{POAhP}+\mathrm{HO} \stackrel{k}{\rightarrow} \mathrm{SOAhP}$

with $k$ the kinetic rate constant equal to $2 \times 10^{-11}$ molecule ${ }^{-1} \mathrm{~cm}^{3} \mathrm{~s}^{-1}$ (Grieshop et al., 2009). SOAIP, SOAmP and SOAhP are the aged SVOC and have respectively partitioning constants of $110.0 \mathrm{~m}^{3} \mu \mathrm{g}^{-1}$, $1.16 \mathrm{~m}^{3} \mu \mathrm{g}^{-1}$ and $0.031 \mathrm{~m}^{3} \mu \mathrm{g}^{-1}$. POAlP, POAmP, and POAhP are assigned an OM/OC ratio of 1.3 whereas SOAIP, SOAmP, and SOAhP are assigned an OM/OC ratio of 1.82 due to oxygen addition.

The second type of mechanism called " $\mathrm{H}^{2} \mathrm{O}-\mathrm{Mech}$ " uses a detailed treatment of primary and aged SVOC where a speciation of primary SVOC is used to attribute molecular structures to primary compounds and to estimate the formation of secondary organic aerosol by aging. The main goal of this mechanism is to attribute molecular structure to primary SVOC and their oxidation products to estimate their activity coefficients in the atmosphere with the UNIversal Functional group Activity Coefficient (UNIFAC) thermodynamic model (Fredenslund et al., 1975). The impact of activity coefficients on the partitioning of primary SVOC and their oxidation products are not taken into account in " $\mathrm{H}^{2} \mathrm{O}$-Ref" whereas it is possible that POA and SOA have low affinities which each other (Pun, 2008; Song et al., 2007). With " $\mathrm{H}^{2} \mathrm{O}-\mathrm{Mech}$ ", the structure of primary SVOC and their oxidation products are known and it is, therefore, possible to estimate the impact of activity coefficients on their partitioning. The speciation is based on the data of Schauer et al. (1999) on the identified fraction of SVOC from medium-duty diesel trucks (14\% of SVOC). Molecules with similar properties (high, medium or low volatility) and type (acids, alkanes, polycyclic aromatic hydrocarbons (PAH)) are lumped into a single surrogate species. Isaacman et al. (2012) found that about $73 \%$ of SVOC above 15 carbons are aliphatic and $27 \%$ are aromatic. With the speciation used in this study, $70 \%$ of SVOC above 15 carbons are aliphatic and $30 \%$ are aromatic. The SVOC speciation used here is, therefore, consistent with the results of Isaacman et al. (2012). Saturation vapor pressures and the emission fractions are chosen to respect the same dilution curve than in the previous approach. Table 1 describes these primary SVOC and their properties.

The surrogate species are then used to develop an oxidation mechanism of primary SVOC. For the species HC17, the oxidation mechanism is based on the data of Presto et al. (2010) by fitting the saturation vapor pressure and mass yields of products. The most volatile product, AnALKF17, was assumed to be a product of first generation (structure of 1,4-hydroxycarbonyls, which has been observed by Lim and Ziemann, 2009a), whereas the less volatile product AnALKS17 was assumed to be of second generation (structure of a hydroxy-dinitrate, which has been observed by Lim and Ziemann, 2009a). For the other species, oxidation was assumed to produce only less volatile species without fractionation. For the alkane species, HC20 and HC24, oxidation was assumed to add one hydroxy and one car-
Table 1. Properties of the different surrogate primary SVOC species.

\begin{tabular}{llrr}
\hline Surrogate & $\begin{array}{l}\text { Molecular } \\
\text { structure }\left(\mathrm{g} \mathrm{mol}^{-1}\right)\end{array}$ & $\begin{array}{r}\text { Saturation vapor } \\
\text { pressure (torr) }\end{array}$ & $\begin{array}{r}\text { Percentage of } \\
\text { emissions }\end{array}$ \\
\hline HC24 & tetracosane & $3.01 \times 10^{-8}$ & $7.38 \%$ \\
ACD18 & octadecanoic acid & $4.80 \times 10^{-8}$ & $9.92 \%$ \\
DIACD18 & octadecanedioic acid & $3.60 \times 10^{-8}$ & $7.70 \%$ \\
HC20 & eicosane & $9.64 \times 10^{-7}$ & $4.60 \%$ \\
PYR & pyrene & $1.94 \times 10^{-6}$ & $27.40 \%$ \\
HC17 & heptadecane & $1.19 \times 10^{-4}$ & $33.11 \%$ \\
FLU & fluorene & $9.95 \times 10^{-5}$ & $3.57 \%$ \\
AROM & methyl-benzoic acid & $1.68 \times 10^{-4}$ & $6.33 \%$ \\
\hline
\end{tabular}

bonyl group (1,4-hydroxycarbonyls are one of the first generation products formed by oxidation of alkanes Lim and Ziemann, 2009a,b). The oxidation of the acid species, ACD18 and DIACD18, was assumed to be similar to the oxidation of the alkanes. For the PAH species, PYR and FLU, oxidation was assumed to add two carbonyl groups $(1,4-$ naphthoquinone and 9,10-phenanthrequinone are among the main products of the oxidation of naphthalene and phenanthrene respectively Wang et al., 2007; Lee and Lane, 2009, 2010; Kautzman et al., 2010). For the aromatics, AROM, oxidation was assumed to add a hydroxy group on the aromatic ring. The effect of a group addition on the saturation vapor pressure was estimated using the method of Pankow and Asher (2008). The kinetics of the oxidation of alkanes are taken from Calvert et al. (2008). The kinetics of the other compounds were fitted to reproduce the results of the first approach with the observed oxidation of Robinson et al. (2007) during the first hours of the oxidation at $10 \mu \mathrm{g} \mathrm{m}^{-3}$ of POA. Reactions leading to SOA formation from primary SVOC oxidation and the properties of the SOA products are presented in Tables 2 and 3, respectively. This mechanism could be improved because it only takes into account one oxidation step, assumes that oxidation only leads to less volatile compounds and because aromatics oxidation products are mainly unsaturated ring-opened products containing aldehyde groups that should oligomerize and react rapidly leading to further aging. Nevertheless, the effect of a single-step aging on activity coefficients and on the interactions between POA and SOA can be estimated with this mechanism.

Formation of SOA from the oxidation of some intermediate volatility organic compounds (IVOC) were also included in " $\mathrm{H}^{2} \mathrm{O}-\mathrm{Mech}$ ". We used results from Schauer et al. (1999) on identified products from diesel exhaust to provide a speciation of IVOC. IVOC are separated into three products: $\mathrm{HC} 15$ for long-chain alkanes, acids and aldehydes (pentadecane is used as surrogate), NAPH for naphthalene and MNAPH for alkylnaphthalenes (2-methylnaphtalene is used as surrogate). IVOC from diesel exhaust was assumed to consist roughly of $79 \%$ of $\mathrm{HC} 15,6 \%$ of NAPH and $15 \%$ of MNAPH. The oxidation of HC15 is chosen to be similar to 
Table 2. Reactions of oxidation of primary SVOC (top panel) and IVOC (bottom panel) species (the oxidant species is listed as both reactant and product to ensure that the gas phase mechanism is not affected by these additional reactions).

\begin{tabular}{ll}
\hline Reaction & $\begin{array}{l}\text { Kinetic rate parameter } \\
(\text { molecule }\end{array}$ \\
\hline $\left.\mathrm{HC} 24+\mathrm{HO} \rightarrow \mathrm{s} \mathrm{s}^{-1}\right)$
\end{tabular}

Table 3. Properties of the different surrogate secondary SVOC species formed from primary SVOC oxidation (top panel) and IVOC oxidation (bottom panel).

\begin{tabular}{lrrr}
\hline Surrogate & $\begin{array}{r}\text { Molecular } \\
\text { weight }\end{array}$ & $\begin{array}{r}\text { Saturation vapor } \\
\text { pressure (torr) }\end{array}$ & OM/OC \\
\hline AnALKF24 & 368 & $2.32 \times 10^{-11}$ & 1.28 \\
AnACD18 & 314 & $3.69 \times 10^{-11}$ & 1.45 \\
AnDIACD18 & 344 & $2.71 \times 10^{-11}$ & 1.59 \\
AnALKF20 & 312 & $7.42 \times 10^{-10}$ & 1.30 \\
AnPYR & 234 & $4.00 \times 10^{-8}$ & 1.22 \\
AnALKF17 & 270 & $1.03 \times 10^{-8}$ & 1.32 \\
AnALKS17 & 378 & $5.32 \times 10^{-7}$ & 1.85 \\
AnFLU & 198 & $2.49 \times 10^{-6}$ & 1.27 \\
AnAROM & 152 & $1.26 \times 10^{-6}$ & 1.58 \\
\hline AnALKF15 & 242 & $7.09 \times 10^{-7}$ & 1.34 \\
AnALKS15 & 350 & $1.34 \times 10^{-8}$ & 1.94 \\
AnPAHIN & 198 & $1.0 \times 10^{-12}$ & 2.06 \\
AnPAHhN & 182 & $1.0 \times 10^{-6}$ & 1.90 \\
\hline
\end{tabular}

that of $\mathrm{HC} 17$ and is based on fitting to data of Presto et al. (2010) for SOA formation from the oxidation of pentadecane. Data from Chan et al. (2009) are used to fit two products from the oxidation of NAPH and MNAPH: AnPAHIN (for SOA formed by PAH oxidation under low- $\mathrm{NO}_{\mathrm{x}}$ conditions) and AnPAHhN (for SOA formed by PAH oxidation under high- $\mathrm{NO}_{\mathrm{x}}$ conditions). The structures for these surrogates, shown in Fig. 1, are those of some major compounds detected under low- $\mathrm{NO}_{\mathrm{x}}$ and high- $\mathrm{NO}_{\mathrm{x}}$ by Kautzman et al. (2010). These two structures seem suitable as surrogate compounds because their OM/OC ratios of 2.06 and 1.90 are similar to the OM/OC ratios for SOA from naphthalene oxidation of 1.96 for low- $\mathrm{NO}_{\mathrm{x}}$ conditions and 1.89 for high- $\mathrm{NO}_{\mathrm{x}}$ conditions found by Chhabra et al. (2010). The kinetics of oxidation of NAPH and MNAPH with $\mathrm{HO}$ are taken from Calvert et al. (2002) for the reaction of naphthalene with HO. To determine whether the radical formed from the oxidation of NAPH or MNAPH $\left(\mathrm{RO}_{2}\right)$ will react under low- $\mathrm{NO}_{\mathrm{x}}$ conditions $\left(\mathrm{RO}_{2}\right.$ reacts with the radical $\mathrm{HO}_{2}$, the methylperoxy radical $\mathrm{MO}_{2}$ or the peroxyacetyl radical $\mathrm{ACO}_{3}$ ) or high $-\mathrm{NO}_{\mathrm{x}}$ conditions $\left(\mathrm{RO}_{2}\right.$ reacts with the radical $\mathrm{NO}_{3}$ or $\left.\mathrm{NO}\right)$, the kinetics of the reactions of the radical formed from toluene oxidation (TOLP) with these radicals used by Couvidat et al. (2012) are used. Reactions leading to SOA formation from 

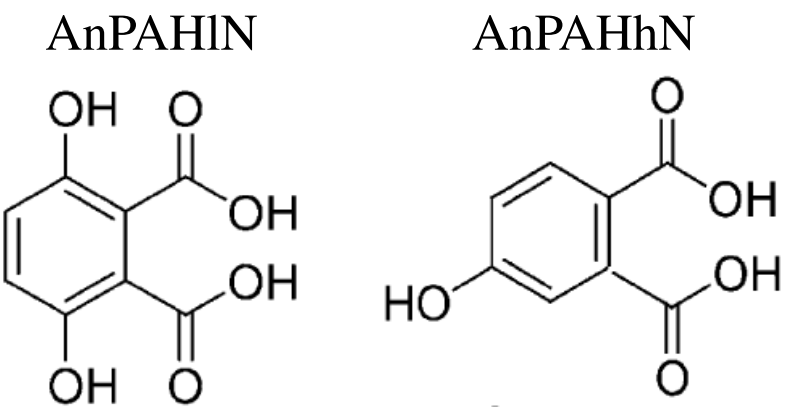

Fig. 1. Molecular structures of AnPAHIN and AnPAHhN used as surrogates for SOA formation from naphthalene and alkylnaphthalene oxidation under low- $\mathrm{NO}_{\mathrm{x}}$ and high- $\mathrm{NO}_{\mathrm{x}}$ conditions, respectively.

IVOC oxidation and the properties of the SOA products are presented in Tables 2 and 3, respectively.

Figure 2 shows the concentrations of SOA from primary SVOC oxidation computed by a box model with the two mechanisms for $10 \mu \mathrm{g} \mathrm{m}^{-3}$ and $1 \mu \mathrm{g} \mathrm{m}^{-3}$ of POA at $298 \mathrm{~K}$ and $[\mathrm{HO}]=2.0 \times 10^{6}$ molecules $\mathrm{cm}^{-3}$ (concentrations used to have an OM evolution similar to Robinson et al., 2007). The two mechanisms " $\mathrm{H}^{2} \mathrm{O}-\mathrm{Ref}$ " and " $\mathrm{H}^{2} \mathrm{O}-\mathrm{Mech}$ ", give similar concentrations of $\mathrm{OM}$ at both low and high organic aerosol loadings whereas these two mechanisms used different approaches. One significant difference between " $\mathrm{H}^{2} \mathrm{O}-$ Mech" and " $\mathrm{H}^{2} \mathrm{O}-\mathrm{Ref}$ " for the formation of SOA from primary SVOC is in the degree of oxidation of SOA. SOA from " $\mathrm{H}^{2} \mathrm{O}-\mathrm{Ref}$ " has a OM/OC ratio of 1.82 , which is rather high for first-generation oxidation products. OM/OC ratios for " $\mathrm{H}^{2} \mathrm{O}-\mathrm{Mech}$ " are more realistic (ratios between 1.27 and 1.85 ) because it uses molecular structures of some firstgeneration oxidation products. " $\mathrm{H}^{2} \mathrm{O}-\mathrm{Mech}$ " and " $\mathrm{H}^{2} \mathrm{O}-\mathrm{Ref}$ " should then give similar amounts of SOA from primary SVOC oxidation, when used in a 3-D air quality model simulation, but " $\mathrm{H}^{2} \mathrm{O}-\mathrm{Mech}$ " should give higher concentrations of OC than "H ${ }^{2} \mathrm{O}-\mathrm{Ref}$ ". Moreover, as the " $\mathrm{H}^{2} \mathrm{O}-\mathrm{Mech}$ " mechanism only takes into account one oxidation step, it probably underestimates aging of SVOC that would become less volatile and more oxidized. More work should be done to develop a complete and more realistic aging mechanism for SOA formation from primary SVOC with numerous oxidation steps. Nevertheless, the use of " $\mathrm{H}^{2} \mathrm{O}-\mathrm{Mech}$ " is useful here to obtain insight on the interaction between POA and SOA species, because such information is not available otherwise from mechanisms such as " $\mathrm{H}^{2} \mathrm{O}-\mathrm{Ref}$ ".

\section{Simulation setup and measurement dataset}

OM was simulated over the Paris area during the Megapoli campaign of July 2009. Input data to Polair3D/Polyphemus were prescribed as follows, the simulation domain being the same as in Royer et al. (2011). Boundary conditions for gaseous and particulate species were obtained from nested simulations over Europe and France. These simulations were conducted using the same data as Couvidat et al. (2012), i.e., the EMEP emission inventory (Vestreng, 2003) was used for anthropogenic emissions and the MEGAN emission model with the EFv2.1 dataset (Guenther et al., 2006) was used for biogenic VOC emissions. For simulations over the Paris area, anthropogenic emissions of gases and particles were obtained from the Airparif (the Paris air quality agency) inventory for the year 2005. Meteorology was simulated with the Weather Research \& Forecasting (WRF) model (WRF) using an urban canopy model and an updated Corine landuse data base (Kim, 2011) with the YSU parameterization (Hong et al., 2006) for the planetary boundary layer (PBL) dynamics.

Emissions of PM from traffic were assumed to consist of $50 \% \mathrm{EC}, 40 \% \mathrm{POA}$, and $10 \%$ non-volatile noncarbonaceous PM based on measurements conducted in Paris in summer 2010 by Airparif (2011). Emissions of EI-POA (Emissions Inventory POA) are transformed into SVOC emissions using a SVOC/EI-POA ratio of 5 as done and discussed by Couvidat et al. (2012). To estimate IVOC, we used an IVOC/SVOC factor of 1.70 based on emissions of Pye and Seinfeld (2010) for anthropogenic sources, which should be the major source of SVOC in the Paris area.

$\mathrm{PM}_{2.5}$ OC was measured at two stations: the SIRTA station (Site Instrumental de Recherche par Télédétection Atmosphérique, Haeffelin et al., 2005), located southwest of Paris in a suburban setting, and the LHVP (Laboratoire d'Hygiène de la Ville de Paris) station located in downtown Paris. Two measurement datasets were used to compare model results to measurements. The first dataset uses daily measurements of $\mathrm{PM}_{2.5} \mathrm{OC}$ and EC with aerosol filters at both stations. $\mathrm{PM}_{2.5}$ filter samples ( $150 \mathrm{~mm}$-diameter quartz fiber filters, Tissuquartz ${ }^{\circledR}$ ) were collected on a 12-h basis, using a high-volume sampler (Digitel, DA-80). A $1 \mathrm{~cm}^{2}$ filter punch was analyzed for elemental carbon (EC) and organic carbon (OC), using a Sunset Lab analyzer and following the EUSAAR 2 protocol temperature program proposed by Cavalli et al. (2010).

The second dataset uses semi-continuous hourly concentrations of $\mathrm{EC}$ and $\mathrm{OC}$ in $\mathrm{PM}_{2.5}$, which were obtained at LHVP from an OCEC Sunset field instrument (Sunset Laboratory, Forest Grove, OR, USA; Bae et al., 2004) running at 8 $\mathrm{L} \mathrm{mn}^{-1}$. A denuder provided by the manufacturer was set upstream in order to remove possible adsorption of VOC onto the filter used to collect $\mathrm{PM}_{2.5}$ in the instrument. Measurement uncertainty given by the OCEC Sunset field instrument is poorly described in literature, although a $20 \%$ uncertainty was estimated by Peltier et al. (2007).

Preliminary comparisons of OC and EC obtained by this instrument have been performed in the region of Paris against low-volume VOC denuded manual filter sampling 

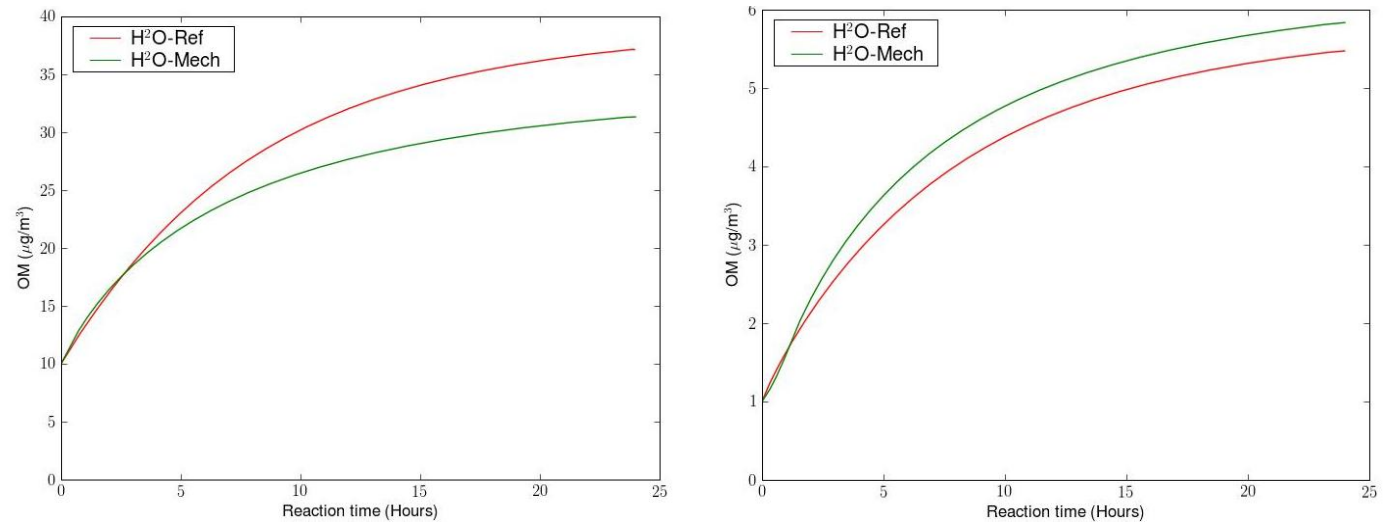

Fig. 2. Concentrations of SOA from primary SVOC oxidation computed with the two mechanisms for $10 \mu \mathrm{g} \mathrm{m}^{-3}$ (left) and $1 \mu \mathrm{g} \mathrm{m}{ }^{-3}$ (right) of POA.

and showed very consistent results (Sciare et al., 2010, 2011). During the Megapoli campaign, a comparison was also performed between EC (OCEC Sunset field instrument) and uncorrected Black Carbon provided by the Aethalometer instrument (Magee Scientific, model AE31) leading also to very satisfactory results $\left(r^{2}=0.96 ; N=620\right.$; with a slope of 1.65 without correction of the mass absorption efficiency; Sciare et al., unpublished data).

During this Megapoli campaign, dynamic filter blanks were performed on a daily basis by placing a total filter upstream of the $\mathrm{PM}_{2.5}$ cyclone of the OCEC Sunset field instrument. A systematic offset of $1.0 \mu \mathrm{g} \mathrm{m}^{-3}$ was found for July 2009. This offset, which depends strongly on the sampled air volume is traditionally considered to be due to VOC absorption (Bae et al., 2004; Arhami et al., 2006; Polidori et al., 2006) and ranges from 0.5 to $2.0 \mu \mathrm{g} \mathrm{m}^{-3}$ (Offenberg et al., 2007). The filters and Sunset instrument measurements are consistent for EC at the LHVP station. However, filter measurements of OC are much higher than the Sunset instrument measurements especially for the second half of July 2009. The differences between the two measurements could be due to condensation of SVOC or adsorption of some VOC on the filter or to the evaporation of some SVOC from the Sunset instrument. However, as OC concentrations during this campaign are very low, it is not surprising that the results from these two measurements are different since the analytical bias (from the sampling and the chemical analysis) are then relatively strong compared to the signal.

Three simulations were conducted: two simulations with the "H ${ }^{2} \mathrm{O}-\mathrm{Ref}$ " mechanism with and without anthropogenic emissions in the Paris area (all other emissions being the same) to estimate the local contribution of OM and one simulation with the the " $\mathrm{H}^{2} \mathrm{O}-\mathrm{Mech}$ " with all emissions. The simulation with " $\mathrm{H}^{2} \mathrm{O}$-Ref" mechanism with anthropogenic emissions reaches the criteria of performance of Russel and Dennis (2000) for ozone (mean normalized bias of $-44.2 \%$ and mean normalized gross error of $15.4 \%$ ) and the model performance goal of Boylan and Russell (2006) for $\mathrm{PM}_{2.5}$ (mean fractional bias of $-9.0 \%$ and mean fractional error of $39 \%)$.

\section{Comparison of the model results with measurements}

Concentrations of EC and OC simulated with " $\mathrm{H}^{2} \mathrm{O}-\mathrm{Ref}$ " are shown in Fig. 3 at the LHVP and SIRTA stations, and are compared with the 12-h filter measurements at both sites and with hourly Sunset field instrument measurements (with or without the offset of $1 \mu \mathrm{g} \mathrm{m}^{-3}$ ) average over 12-h at the LHVP site. Comparisons with measurements for EC and OC are shown in Figs. 4 and 5, respectively with correlations and root mean square errors (RMSE) between filter measurements and model concentrations.

The model reproduces the high concentrations of $\mathrm{OC}$ at the SIRTA and LHVP sites on 1 July, which is a day of high pollution (Royer et al., 2011) and shows satisfactory results at the SIRTA site for EC and OC, although they are both slightly overestimated $\left(0.50 \mu \mathrm{g} \mathrm{m}^{-3}\right.$ of modeled EC against $0.38 \mu \mathrm{g} \mathrm{m}^{-3}$ in measurements and $2.64 \mu \mathrm{g} \mathrm{m}^{-3}$ of modeled OC against $2.27 \mu \mathrm{g} \mathrm{m}^{-3}$ in measurements). As EC is an inert pollutant (i.e. it does not undergo chemical transformation), it may indicate an overestimation of anthropogenic emissions near the SIRTA site. At the LHVP site, the model shows satisfactory results for EC until 26 July $\left(1.08 \mu \mathrm{g} \mathrm{m}^{-3}\right.$ of modeled EC against $1.03 \mu \mathrm{g} \mathrm{m}^{-3}$ in filter measurements) but greatly underestimates EC and OC concentrations between 26 and 29 July $\left(1.22 \mu \mathrm{g} \mathrm{m}^{-3}\right.$ of modeled EC on average against $2.11 \mu \mathrm{g} \mathrm{m}^{-3}$ in filter measurements). This underestimation could be explained by difficulties in modeling urban meteorology and/or underestimation of emissions due to missing sources: high traffic emissions due to holiday departures, meteorology potentially favorable to PM resuspension, missing emissions of particles from cooking from the Airparif inventory, whereas cooking was found by Prevot et al. 

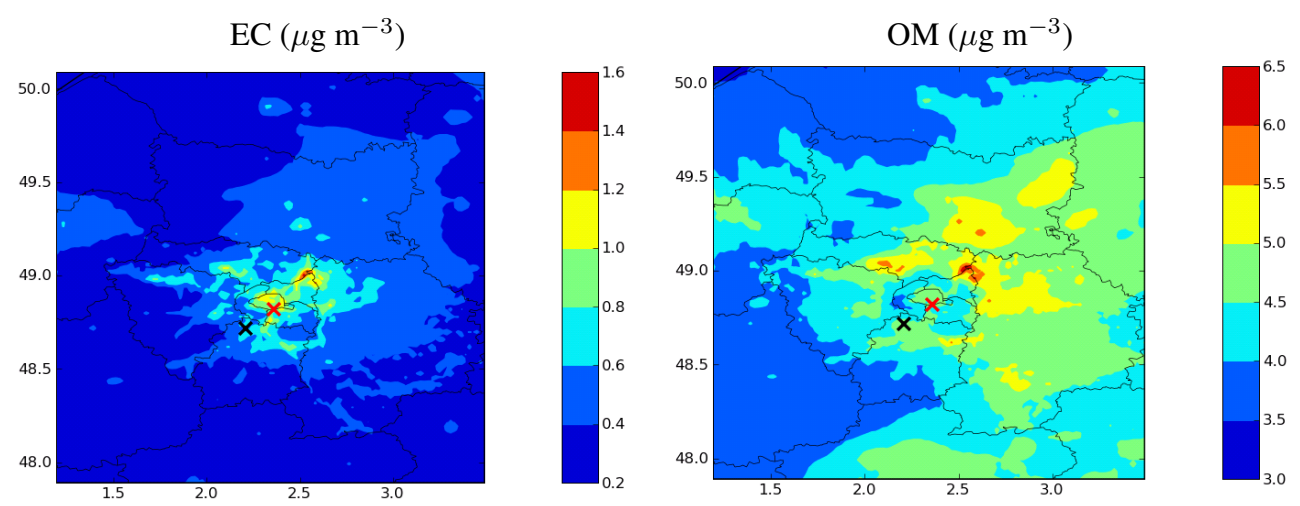

Fig. 3. Simulated concentrations in $\mu \mathrm{g} \mathrm{m}^{-3}$ of EC (left) and OM (right) for July 2009. The red and black crosses correspond to the LHVP and SIRTA sites, respectively.
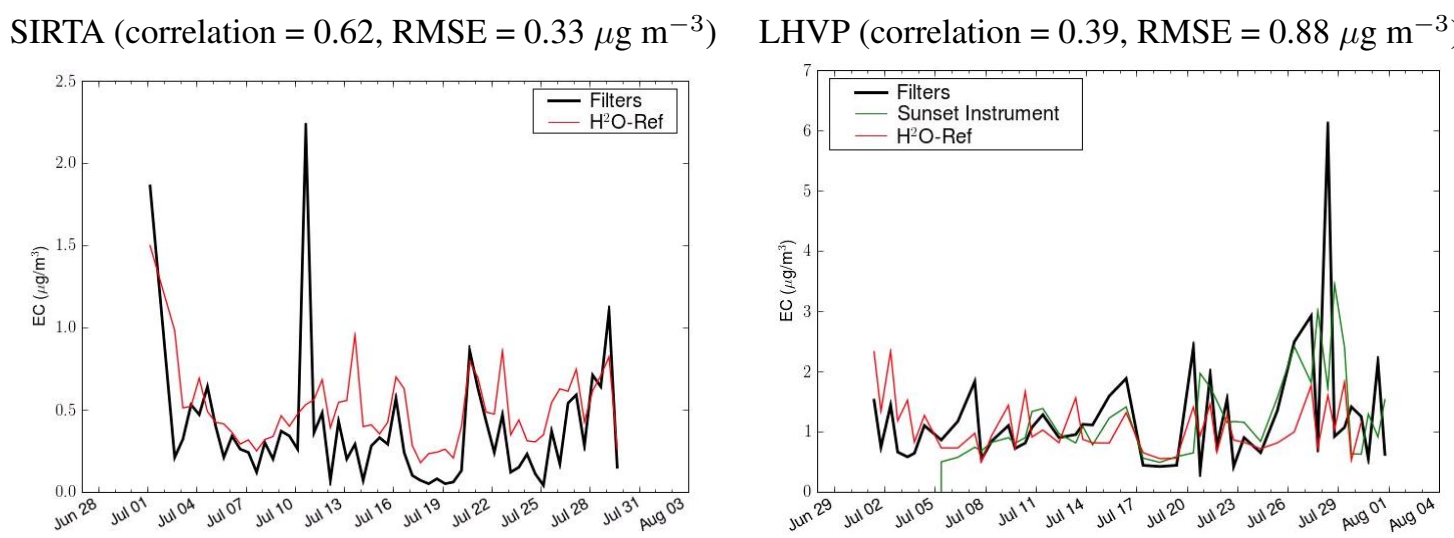

Fig. 4. $12 \mathrm{~h}$ averaged concentrations of EC modeled with " $\mathrm{H}^{2} \mathrm{O}-\mathrm{Ref}$ " and measured with filters at the SIRTA site (left) and with both filters and Sunset filed instrument at the LHVP (right) site (correlations and RMSE are between the model and the filter measurements).

(2011) to be one of the main sources of organic aerosols in the Paris city center.

The modeled OC concentrations generally fall between the Sunset instrument measurements with and without offset, but are much lower than the filter measurements (on average, $2.87 \mu \mathrm{g} \mathrm{m}^{-3}$ of modeled OC, $3.15 \mu \mathrm{g} \mathrm{m}^{-3}$ of measured OC with the Sunset instrument with the offset and $3.73 \mu \mathrm{g} \mathrm{m}^{-3}$ of measured OC with filter measurements). The modeled concentration peaks of OC are generally observed by the filter measurements but are not observed by the Sunset field instrument (for example, the peaks of 20, 28 and 29 July). Thus, the correlation coefficient $(r)$ between the model and the filter measurements $(r=0.75)$ is much higher than the correlation coefficient between the model and the Sunset field instrument measurements $(r=0.49)$. Due to the differences between measurements performed with filters and the Sunset instrument, it is difficult to conclude if the model underestimates or overestimates OC concentrations.

Since the Sunset instrument measurements are hourly, they provide insight into the temporal profiles of EC and $\mathrm{OC}$ at the LHVP station. Figure 6 shows the measured and modeled daily temporal profiles for EC and OC at the LHVP station from 5 to 25 July (i.e., the period during which the Sunset instrument, the filters and the model give similar EC concentrations). As shown in this figure, " $\mathrm{H}^{2} \mathrm{O}-\mathrm{Ref}$ " shows two peaks corresponding to high EC emissions from traffic during rush hours. The first peak reproduces well the Sunset instrument measurements. However, the model also shows high EC concentrations between 10:00 a.m. and 08:00 p.m. with a peak at 04:00-05:00 p.m. and low concentrations after 08:00 p.m. whereas the measurements show low concentrations between 08:00 a.m. and 08:00 p.m. and an increase in concentrations after 08:00 p.m.. This could be due to an incorrect temporal profile for traffic emissions in the Airparif inventory. Menut et al. (2012) studied the impact of hourly emission profiles and provided more realistic temporal profiles of traffic emissions for some cities (including Paris). Figure 7 shows the temporal profiles of traffic emissions of the Airparif inventory and Menut et al. (2012). The emission profile of the Airparif inventory gives very high emissions at the end of the afternoon whereas emissions from the temporal profile of Menut et al. (2012) (noted TPM hereafter) are much lower 

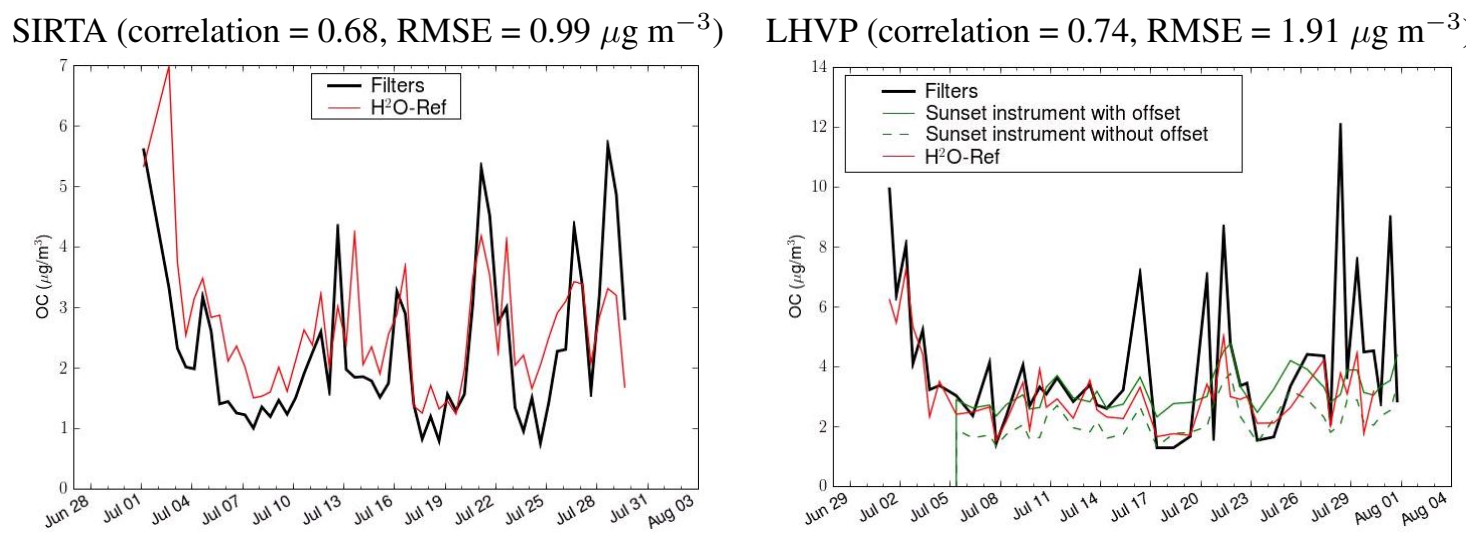

Fig. 5. $12 \mathrm{~h}$ averaged concentrations of OC modeled with " $\mathrm{H}^{2} \mathrm{O}$-Ref" and measured with filters at the SIRTA (left) and with both filters and Sunset field instrument at the LHVP (right) site (correlations and RMSE are between the model and the filter measurements).
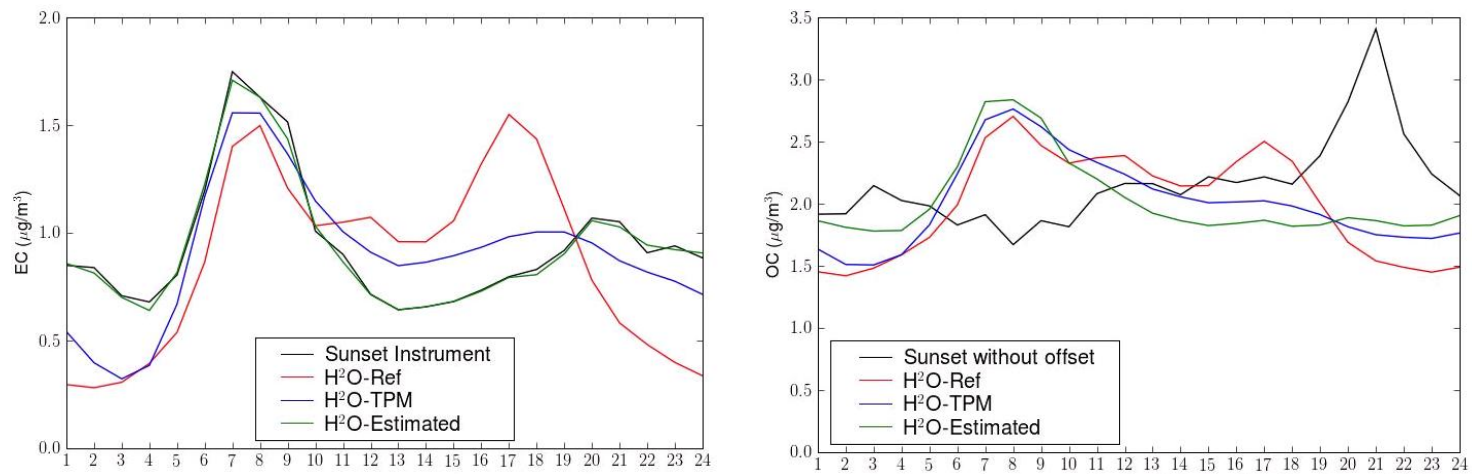

Fig. 6. Measured and modeled daily temporal profiles for EC (left) and OC (right) at the LHVP site from 5 to 25 July 2009 . $\mathrm{H}^{2} \mathrm{O}-\mathrm{TPM}$ stands for the results of " $\mathrm{H}^{2} \mathrm{O}$-Ref" with the temporal profile of Menut et al. (2012) for traffic emissions; $\mathrm{H}^{2} \mathrm{O}$-Estimated corresponds to the use of an estimated emission temporal profile that matches the observed temporal profile of EC.

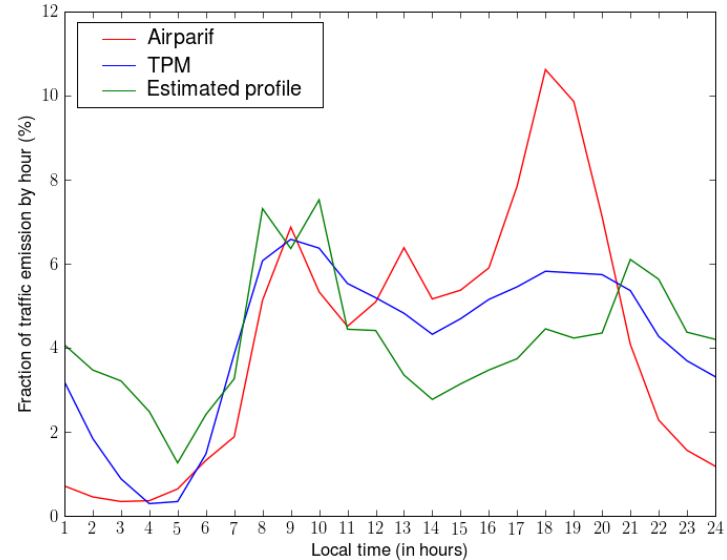

Fig. 7. Temporal profiles of traffic emissions from the Airparif inventory, from Menut et al. (2012) (TPM) and from matching EC observations at the LHVP station (Estimated profile). in the afternoon and higher at the end and beginning of the day. Using TPM gives better results with lower EC concentrations during the afternoon and higher EC concentrations at night, but the second peak of concentrations given by the model still occurs too early and night concentrations are still too low (see Fig. 6). Underestimation of EC concentrations at night could be due to the overestimation of the nighttime PBL height by WRF using the YSU parameterization. It is also possible that TPM does not reproduce exactly the temporal profile of summer traffic emissions, because TPM is estimated by averaging "near traffic" concentrations values measured on Mondays during a whole year. This temporal profile is, therefore, an average temporal profile and is not specific to July, when holidays may strongly affect the emission profile. To address this potential source of uncertainty, a temporal profile of traffic emissions was estimated by matching the temporal profile of EC concentrations. This estimated temporal profile of traffic emissions is shown in Fig. 7 and the corresponding modeled EC concentration profile is shown in Fig. 6. 


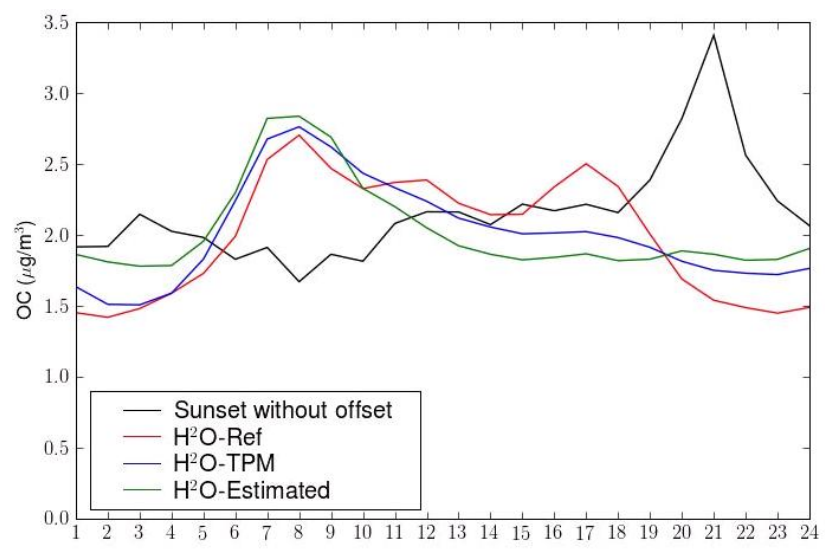

Fig. 8. Simulation of the daily temporal profiles of secondary OC compared with the daily temporal profile of measured OC (see Fig. 7 for simulation descriptions).

For OC concentrations, except for a peak at $10 \mathrm{pm}$, the measured temporal profile (shown Fig. 6) is almost constant with concentrations around $2.0 \mu \mathrm{g} \mathrm{m}^{-3}$ without the offset. Allan et al. (2010) found high concentrations of organic aerosols due to cooking between 08:00 p.m. and 10:00 p.m. in London and Manchester. The 10:00 p.m. peak observed in Paris could then be due to cooking activities. In that case, since cooking emissions are missing from the inventory, the model should not be able to reproduce this peak. The peaks of EC corresponding to rush-hour high emissions do not appear in the observed temporal profile of OC. "H ${ }^{2} \mathrm{O}-\mathrm{Ref}$ " gives two peaks corresponding to high emissions from traffic given by the Airparif inventory, which do not appear in the measurements. However, the second OC peak disappears when TPM (which gives lower emissions in the afternoon and higher emissions at night) is used but the first peak is unchanged. Using the estimated temporal profile of traffic emissions confirms the disappearance of the second peak but could not explain the absence of the first peak which clearly appears in the temporal profile of EC.

One possible explanation is that evaporation of POA is underestimated by the model. This is possible since evaporation of POA is based on results of Robinson et al. (2007), which are based on measurements for organic loading higher than $20 \mu \mathrm{g} \mathrm{m}^{-3}$. Partitioning of primary SVOC is then highly uncertain at the conditions of the simulation with OC concentrations around $2 \mu \mathrm{g} \mathrm{m}^{-3}$. Primary SVOC may not condense and organic aerosols could then be secondary. It is also possible that the gas-particle partitioning of primary SVOC is affected by temperature and that an underestimation of temperature during the morning rush hours could lead to a slight overestimation of POA. However, no measurements of temperature are available during the campaign at the LHVP site and therefore comparisons can not be made to verify if the temperature at this site is underestimated. Figure 8 shows the secondary OC (SOC) concentrations. This profile is rel-

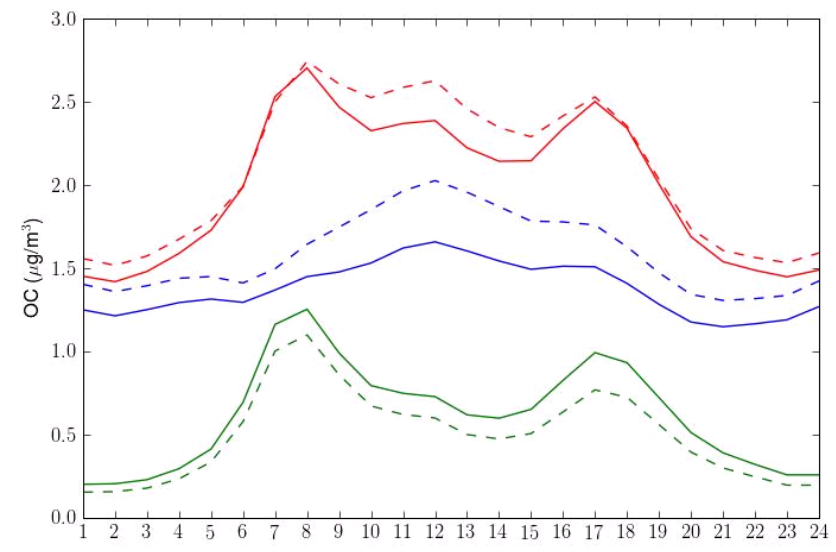

Fig. 9. Comparison of modeled temporal profiles of OC (in red), SOC (in blue) and POC (in green) between " $\mathrm{H}^{2} \mathrm{O}-\mathrm{Ref}$ " (solid lines) and of " $\mathrm{H}^{2} \mathrm{O}-\mathrm{Mech}$ " (dashed lines).

atively constant around $1.7 \mu \mathrm{g} \mathrm{m}^{-3}$ with a small increase to $2.1 \mu \mathrm{g} \mathrm{m}^{-3}$ and, except for the evening peak, this profile is very similar to the profile of OC measured by the Sunset instrument. It may indicate that primary SVOC from traffic did not condense in Paris in July 2009 or that POA from traffic were not captured by the Sunset field instrument, which could then explain the differences between the Sunset field instruments and the filter measurements.

\section{Comparison of two mechanisms for primary SVOC aging}

A comparison of $\mathrm{OC}$, SOC and primary organic carbon (POC) concentrations between " $\mathrm{H}^{2} \mathrm{O}-\mathrm{Ref}$ " and " $\mathrm{H}^{2} \mathrm{O}-\mathrm{Mech}$ " is shown in Fig. 9 and the OM/OC ratios for July 2009 computed with the two mechanisms are shown in Fig. 10. The $\mathrm{OM} / \mathrm{OC}$ ratios computed with " $\mathrm{H}^{2} \mathrm{O}-\mathrm{Ref}$ " are higher than the $\mathrm{OM} / \mathrm{OC}$ ratios computed with " $\mathrm{H}^{2} \mathrm{O}-\mathrm{Mech}$ ". This difference is due to the lower OM/OC ratios of oxidized SVOC formed from the oxidation of primary SVOC in " $\mathrm{H}^{2} \mathrm{O}-\mathrm{Mech}$ " (between 1.27 and 1.85) than in " $\mathrm{H}^{2} \mathrm{O}-\mathrm{Ref}$ " (equal to 1.82). However, only one oxidation step is taken into account in " $\mathrm{H}^{2} \mathrm{O}-\mathrm{Mech}$ " and, in reality, oxidized SVOC should be more oxidized as numerous oxidation steps could occur. " $\mathrm{H}^{2} \mathrm{O}$ Ref" gives an OM/OC ratio around 1.6 in Paris area; these results are consistent with the results of Turpin and Lim (2001) for urban areas. Concentrations of POC are lower with " $\mathrm{H}^{2} \mathrm{O}-\mathrm{Mech}$ " than with " $\mathrm{H}^{2} \mathrm{O}-\mathrm{Ref}$ ". As the organic aerosol loading into which SVOC can be absorbed is the same in the two mechanisms, the lower concentrations of POC with " $\mathrm{H}^{2} \mathrm{O}-\mathrm{Mech}$ " is due to the impact of activity coefficients on the partitioning of primary SVOC (which is not taken into account in " $\mathrm{H}^{2} \mathrm{O}$-Ref"). It indicates that primary SVOC condense less readily on an oxidized aerosol. This point could be very important for SVOC partitioning in 

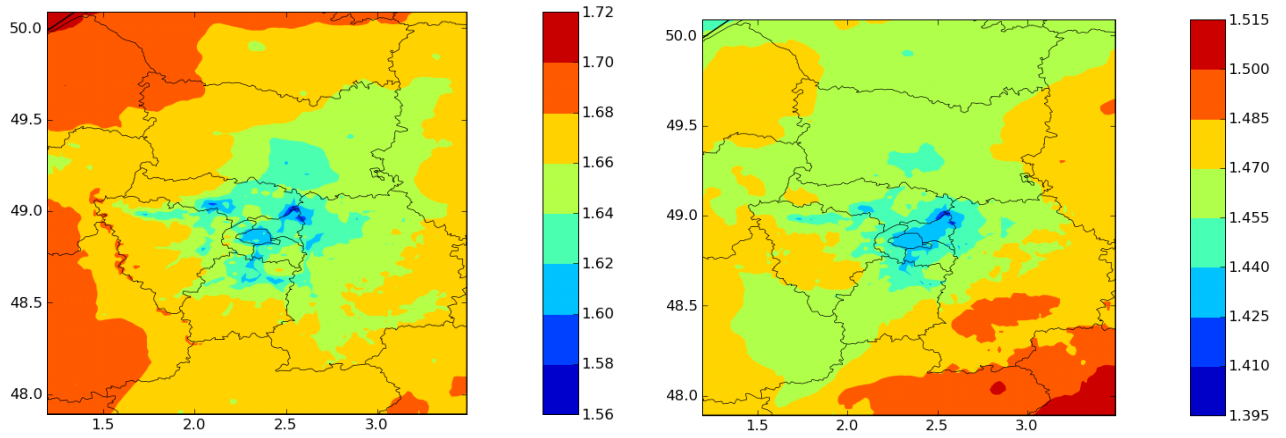

Fig. 10. Modeled OM/OC ratios with " $\mathrm{H}^{2} \mathrm{O}-\mathrm{Ref}$ " (left) and " $\mathrm{H}^{2} \mathrm{O}-\mathrm{Mech}$ " (right).

the atmosphere and, since " $\mathrm{H}^{2} \mathrm{O}$-Mech" only takes into account one oxidation step whereas numerous oxidation steps are likely to occur in the atmosphere, this effect could be even greater than simulated here. The secondary aerosol should be more oxidized in reality than in the model and primary SVOC are possibly unable to condense on an oxidized aerosol. Those results are confirmed by experimental studies: POA and SOA were shown to possibly not mix (Song et al., 2007) or to mix but with interactions between compounds influencing the partitioning of SVOC (Asa-Awuku et al., 2009).

In contrast, SOC formation is higher in " $\mathrm{H}^{2} \mathrm{O}-\mathrm{Mech}$ " than in " $\mathrm{H}^{2} \mathrm{O}-\mathrm{Ref}$ " but SOA concentrations are similar (as shown in Fig. 11). Figure 11 shows that biogenic SOA are similar with the two mechanisms. However, the concentrations of biogenic hydrophobic compounds (BiNIT, BiNIT3, BiNGA, BiBlP, BiBmP, AnBlP, AnBmP which are described in Couvidat et al., 2012), which are absorbed into the organic phase, concentrations are increased by $10 \%$. The higher concentration of biogenic hydrophobic SOA compounds with " $\mathrm{H}^{2} \mathrm{O}$ Mech" is due to lower activity coefficients. " $\mathrm{H}^{2} \mathrm{O}$-Ref" uses for the computation of activity coefficients the same molecular structure as primary SVOC (POAIP, POAmP, POAhP) for SOA formed from the oxidation of primary SVOC (SOAIP, SOAmP, SOAhP) and, therefore, it does not take into account the fact that these SOA compounds are more oxidized than the primary compounds; this phenomenon is taken into account in " $\mathrm{H}^{2} \mathrm{O}-\mathrm{Mech}$ ". As the organic aerosol should be more oxidized in reality than they are in " $\mathrm{H}^{2} \mathrm{O}-\mathrm{Mech}$ " (because the model takes into account only one oxidation step), the condensation of some hydrophobic compounds leading to more SOA formation may be underestimated. Concentrations of SOA formed from IVOC oxidation are not insignificant (the average concentration at noon is $0.4 \mu \mathrm{g} \mathrm{m}^{-3}$ ) but are low compared to SOA formation from SVOC oxidation.

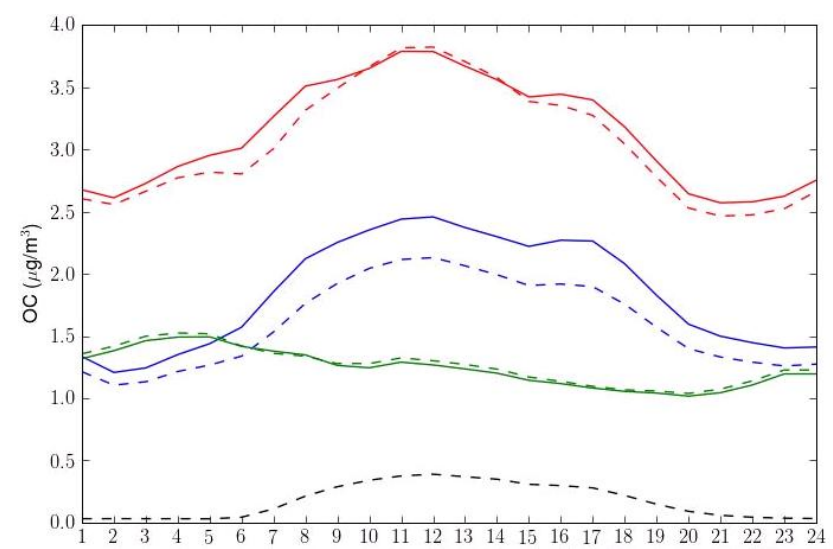

Fig. 11. Modeled temporal profiles of total SOA (in red), of SOA from primary SVOC oxidation (in blue), of biogenic SOA (in green), and of SOA from IVOC oxidation - in black) for " $\mathrm{H}^{2} \mathrm{O}$ Ref" (solid lines) and for "H²O-Mech" (dashed lines).

\section{Origins of particulate organic matter in the Paris area}

The fraction of carbonaceous aerosol originating from the Paris area (i.e., from local sources) is estimated with " $\mathrm{H}^{2} \mathrm{O}$ Ref" by subtracting the results of a simulation without the anthropogenic emissions in the Paris area from the results of the base simulation, i.e., with those anthropogenic emissions. Figure 12 shows concentrations of EC and OM and the local contribution of anthropogenic sources for July 2009. Whereas EC is found to be almost entirely of local origin, $\mathrm{OM}$ inside Paris is found to have both local and regional contributions. About 30 to $38 \%$ of $\mathrm{OM}$ in the city center of Paris (30\% at the LVHP site) can be attributed to local sources during July 2009. This result is commensurate with those obtained by Airparif (2011) using a receptor-based approach: they estimated that at a background urban site, $27 \%$ of OM was of local origin. Figure 13 shows the composition of OM given by " $\mathrm{H}^{2} \mathrm{O}$-Ref" at the LHVP and SIRTA sites. OM has a similar composition at the two sites, but there are more primary SVOC that have been oxidized at 

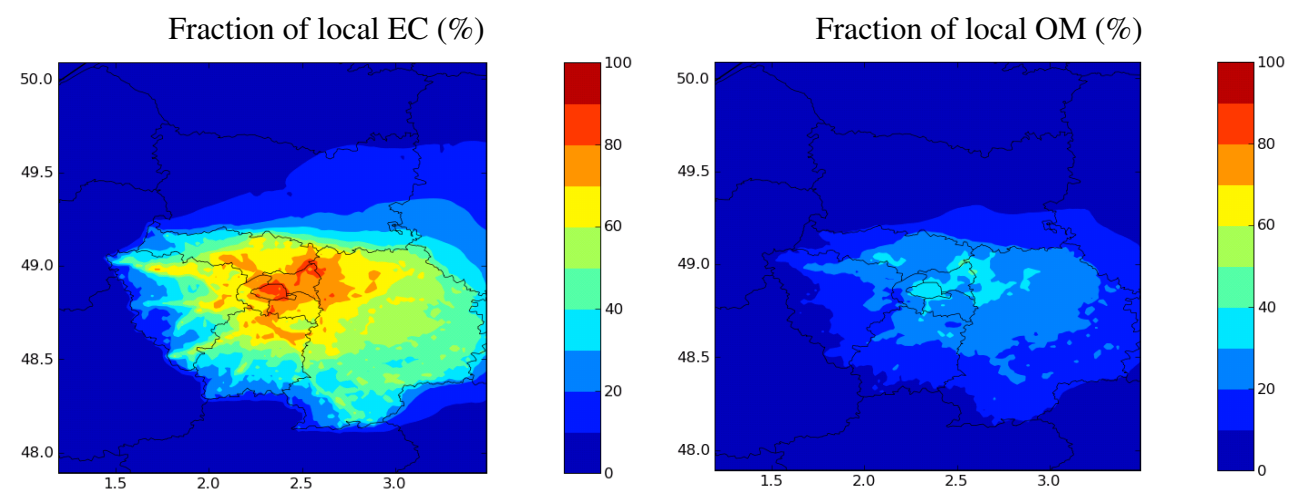

Fig. 12. Fraction of local aerosol in \% (bottom) for EC (left) and OM (right) for July 2009.
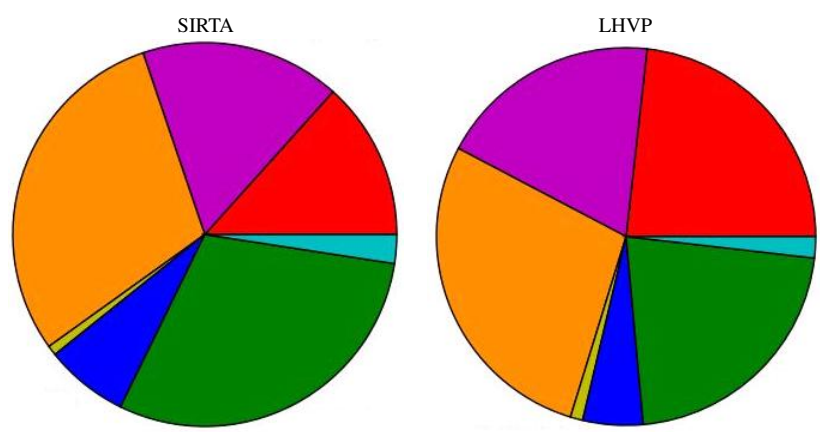

Fig. 13. Averaged composition of $\mathrm{OM}$ at the SIRTA (left) and LHVP (right) sites modeled with " $\mathrm{H}^{2} \mathrm{O}-\mathrm{Ref}$ ". Red: POA, purple: SOA formed form oxidation of primary SVOC, orange: OM from boundary conditions used for the European simulation (longrange transport of OM), yellow: SOA formed from aromatics oxidation, blue: SOA formed from monoterpenes oxidation, green: SOA formed from sesquiterpenes oxidation, aqua: SOA formed from isoprene oxidation.

the suburban SIRTA site. At the LHVP site, OM consists of aerosols from the boundary conditions of the European simulation (28\%), POA (23\%), SOA formed from primary SVOC oxidation (19\%), SOA formed by oxidation of biogenic precursors $(29 \%)$, and SOA formed by oxidation of aromatic precursors $(1 \%)$.

We defined the amount of local aerosol by the difference between two simulations with or without anthropogenic emissions. However, the system is not linear. For example, the concentrations of some surrogates are higher over Paris with anthropogenic emissions due to the increase of the absorbing media even they come from distant sources. $16 \%$ of SOA formed from sesquiterpene oxidation is then found to be local. On the contrary, SOA concentrations from isoprene oxidation increase by $28 \%$ when anthropogenic emissions over Paris are removed. This is due to lower $\mathrm{NO}_{\mathrm{x}}$ concentrations: instead of being oxidized under high- $\mathrm{NO}_{\mathrm{x}}$ conditions, isoprene is oxidized under low- $\mathrm{NO}_{\mathrm{x}}$ conditions and forms SOA with higher yields. As the effect of $\mathrm{NO}_{\mathrm{x}}$ concentrations is not taken into account for monoterpenes and sesquiterpenes, it is possible that more SOA could be formed from these precursors without anthropogenic emissions over the Paris area.

\section{Conclusions}

Organic aerosol formation was simulated over the Paris area during July 2009. Results of the model simulations were compared to measurements conducted during the Megapoli campaign. The model simulated a morning peak of concentrations due to rush-hour traffic for both EC and OC; however, this peak appears in the EC measurements, but does not appear in the OC measurements. This discrepancy between the model and the measurements could be due to the underestimation of POA evaporation at low organic loading by the model, to uncertainties in the modeled temperature, which can affect the gas-particle partitioning or to POA from traffic, which would not be captured by the Sunset field instrument. Using a mechanism for oxidation of primary SVOC that takes into account the molecular structure of primary and secondary surrogate molecules and, therefore, includes explicitly the effect of activity coefficients on SVOC gas/particle partitioning, it was found that oxidized organic aerosols have low affinity with POA and that POA and SOA do not mix well together. Condensation of primary SVOC is likely to be overestimated by a model that does not fully account for the non-ideality of the organic condensed phase, whereas SOA is likely to be underestimated. Moreover, treating the organic aerosol solution as a one-phase ideal solution or using simple partitioning constants (which do not take into account the affinity of a compound with the liquid aerosol solutions) probably overestimates the condensation of primary SVOC.

Organic aerosols in Paris were found to be mainly anthropogenic with 30 to $40 \%$ of OM due to local sources. According to the model, most of the OM results from the condensation of primary SVOC and their oxidation products. Biogenic VOC form only a small quantity of SOA ( $29 \%$ of OM) and are minor precursors in this simulation. Comparisons of 
modeled biogenic SOA concentrations with molecular SOA tracer measurements are needed to confirm this result and evaluate the biogenic emission inventory for Europe.

Acknowledgements. This work was funded in part by ADEME, the French Agency for the Environment and Energy Management and by European Union's Seventh Framework Programme FP/20072011 with the project Megapoli, grant agreement no. 212520, and from the French ANR Megapoli-Paris project. Thanks are due to Airparif, the Paris region air quality agency, for providing us with their air pollutant emission inventory. We also thank the staff of LHVP and SIRTA for hosting measurements and for technical and logical support and J. B. Nicolas and R. Sarda-Estève for their help in the field.

Edited by: J.-L. Jimene

\section{References}

Airparif: Source apportionment of airborne particles in Ile-deFrance - Final Report, Tech. rep., Airparif, Paris, France, 2011.

Allan, J. D., Williams, P. I., Morgan, W. T., Martin, C. L., Flynn, M. J., Lee, J., Nemitz, E., Phillips, G. J., Gallagher, M. W., and Coe, H.: Contributions from transport, solid fuel burning and cooking to primary organic aerosols in two UK cities, Atmos. Chem. Phys., 10, 647-668, doi:10.5194/acp-10-647-2010, 2010.

Arhami, M., Kuhn, T., Fine, P. M., Delfino, R. J., and Sioutas, C.: Effects of sampling artifacts and operating parameters on the performance of a semicontinuous particulate elemental carbon/organic carbon monitor, Environ. Sci. Tech., 40, 945-954, doi:10.1021/es0510313, 2006.

Asa-Awuku, A., Miracolo, M. A., Kroll, J. H., Robinson, A. L., and Donahue, N. M.: Mixing and phase partitioning of primary and secondary organic aerosols, Geophys. Res. Lett., 36, L15827, doi:10.1029/2009GL039301, 2009.

Bae, M.-S., Schauer, J. J., DeMinter, J. T., Tuner, J. R., Smith, D., and Cary, R. A.: Validation of a semi-continuous instrument for elemental carbon and organic carbon using a thermal-optical method, Atmos. Environ., 38, 2885-2893, doi:10.1016/j.atmosenv.2004.02.027, 2004.

Boylan, J. W. and Russell, A. G.: PM and light extinction model performance metrics, goals, and criteria for threedimensional air quality models, Atmos. Environ., 40, 49464959, doi:10.1016/j.atmosenv.2005.09.087, 2006.

Calvert, J. G., Atkinson, R., Becker, K. H., Kamens, R. M., Seinfeld, J. H., Wallington, T. J., and Yarwood, G.: The mechanisms of atmospheric oxidation of the aromatic hydrocarbons, Oxford University Press, 2002.

Calvert, J. G., Derwent, R. G., Orlando, J. J., Tyndall, G. S., and Wallington, T. J.: Mechanisms of atmospheric oxidation of the alkanes, Oxford University Press, 2008.

Carlton, A. G., Wiedinmyer, C., and Kroll, J. H.: A review of Secondary Organic Aerosol (SOA) formation from isoprene, Atmos. Chem. Phys., 9, 4987-5005, doi:10.5194/acp-9-4987-2009, 2009.

Cavalli, F., Viana, M., Yttri, K. E., Genberg, J., and Putaud, J.-P.: Toward a standardised thermal-optical protocol for measuring atmospheric organic and elemental carbon: the EUSAAR protocol, Atmos. Meas. Tech., 3, 79-89, doi:10.5194/amt-3-79-2010, 2010.

Chan, A. W. H., Kautzman, K. E., Chhabra, P. S., Surratt, J. D., Chan, M. N., Crounse, J. D., Kürten, A., Wennberg, P. O., Flagan, R. C., and Seinfeld, J. H.: Secondary organic aerosol formation from photooxidation of naphthalene and alkylnaphthalenes: implications for oxidation of intermediate volatility organic compounds (IVOCs), Atmos. Chem. Phys., 9, 3049-3060, doi:10.5194/acp-9-3049-2009, 2009.

Chhabra, P. S., Flagan, R. C., and Seinfeld, J. H.: Elemental analysis of chamber organic aerosol using an aerodyne high-resolution aerosol mass spectrometer, Atmos. Chem. Phys., 10, 4111-4131, doi:10.5194/acp-10-4111-2010, 2010.

Couvidat, F. and Seigneur, C.: Modeling secondary organic aerosol formation from isoprene oxidation under dry and humid conditions, Atmos. Chem. Phys., 11, 893-909, doi:10.5194/acp-11893-2011, 2011.

Couvidat, F., Debry, É., Sartelet, K., and Seigneur, C.: A hydrophilic/hydrophobic organic $\left(\mathrm{H}^{2} \mathrm{O}\right)$ model: Model development, evaluation and sensitivity analysis, J. Geophys. Res., 117, D10304, doi:10.1029/2011JD017214, 2012.

Debry, E., Fahey, K., Sartelet, K., Sportisse, B., and Tombette, M.: Technical Note: A new SIze REsolved Aerosol Model (SIREAM), Atmos. Chem. Phys., 7, 1537-1547, doi:10.5194/acp-7-1537-2007, 2007.

Donahue, N. M., Robinson, A. L., Stanier, C. O., and N., P. S.: Coupled Partitioning, Dilution, and Chemical Aging of Semivolatile Organics, Environ. Sci. Technol., 40, 2635-2643, doi:10.1021/es052297c, 2006.

Dzepina, K., Cappa, C. D., Volkamer, R. M., Madronich, S., DeCarlo, P. F., Zaveri, R. A., and Jimenez, J. L.: Modeling the multiday evolution and aging of secondary organic aerosol during MILAGRO 2006, Environ. Sci. Technol., 45, 3496-3503, doi:10.1021/es103186f, 2011.

Ervens, B., Turpin, B. J., and Weber, R. J.: Secondary organic aerosol formation in cloud droplets and aqueous particles (aqSOA): a review of laboratory, field and model studies, Atmos. Chem. Phys., 11, 11069-11102, doi:10.5194/acp-1111069-2011, 2011.

Fredenslund, A., Jones, R., and Prausnitz, J.: Group-contribution estimation of activity-coefficients in nonideal liquid-mixtures, AIChE J., 21, 1086-1099, 1975.

Grieshop, A. P., Logue, J. M., Donahue, N. M., and Robinson, A. L.: Laboratory investigation of photochemical oxidation of organic aerosol from wood fires 1: measurement and simulation of organic aerosol evolution, Atmos. Chem. Phys., 9, 1263-1277, doi:10.5194/acp-9-1263-2009, 2009.

Griffin, R. J., Dabdub, D., Kleeman, M. J., Fraser, M., P., Cass, G. R., and Seinfeld, J. H.: Secondary organic aerosol, 3, Urban/regional scale model of size- and composition-resolved aerosols, J. Geophys. Res., 107, 4334, doi:10.1029/2001JD000544, 2002.

Guenther, A., Karl, T., Harley, P., Wiedinmyer, C., Palmer, P. I., and Geron, C.: Estimates of global terrestrial isoprene emissions using MEGAN (Model of Emissions of Gases and Aerosols from Nature), Atmos. Chem. Phys., 6, 3181-3210, doi:10.5194/acp-63181-2006, 2006. 
Haeffelin, M., Barthès, L., Bock, O., Boitel, C., Bony, S., Bouniol, D., Chepfer, H., Chiriaco, M., Cuesta, J., Delanoë, J., Drobinski, P., Dufresne, J.-L., Flamant, C., Grall, M., Hodzic, A., Hourdin, F., Lapouge, F., Lemaître, Y., Mathieu, A., Morille, Y., Naud, C., Noël, V., O'Hirok, W., Pelon, J., Pietras, C., Protat, A., Romand, B., Scialom, G., and Vautard, R.: SIRTA, a ground-based atmospheric observatory for cloud and aerosol research, Ann. Geophys., 23, 253-275, doi:10.5194/angeo-23-253-2005, 2005.

Hodzic, A., Jimenez, J. L., Madronich, S., Canagaratna, M. R., DeCarlo, P. F., Kleinman, L., and Fast, J.: Modeling organic aerosols in a megacity: potential contribution of semi-volatile and intermediate volatility primary organic compounds to secondary organic aerosol formation, Atmos. Chem. Phys., 10, 5491-5514, doi:10.5194/acp-10-5491-2010, 2010.

Hong, S.-Y., Noh, Y., and Dudhia, J.: A new vertical diffusion package with an explicit treatment of entrainment processes, Mon. Weather Rev., 134, 2318-2341, doi:10.1175/MWR3199.1, 2006.

Isaacman, G., Wilson, K. R., Chan, W. H., Worton, D. R., Kimmel, J. R., Nah, T., Hohaus, T., Gonin, M., Kroll, J. H., Worsnop, D. R., and Goldstein, A. H.: Improved resolution of hydrocarbon structures and constitutional isomers in complex mixtures using gas chromatography-vacuum ultraviolet-mass spectrometry, Anal. Chem., 84, 2335-2342, doi:10.1021/ac2030464, 2012.

Jimenez, J. L., Canagaratna, M. R., Donahue, N. M., Prevot, A. S. H., Zhang, Q., Kroll, J. H., DeCarlo, P. F., Allan, J. D., Coe, H., Ng, N. L., Aiken, A. C., Docherty, K. S., Ulbrich, I. M., Grieshop, A. P., Robinson, A. L., Duplossy, J., Smith, J. D., Wilson, K. R., Lanz, V. A., Hueglin, C., Sun, Y. L., Tian, J., Laaksonen, A., Raatikainen, T., Rautiainen13, J., Vaattovaara, P., Ehn, M., Kulmala, M., Tomlinson, J. M., Collins, D. R., Cubison, M. J., Dunlea, E. J., Huffman, J. A., Onash, T. B., Alfarra, M. R., Williams, P. I., Bower, K., Kondo, Y., Schneider, J., Drewnick, F., Borrmann, S., Weimer, S., Demerjian, K., Salcedo, D., Cottrell, L., Griffin, R., Takami, A., Miyoshi, T., Hatakeyama, S., Shimono, A., Sun, J. Y., Zhang, Y. M., Dzepina, K., Kimmel, J. R., Sueper, D., Jayne, J. T., Herndon, S. C., Trimborn, A. M., Williams, L. R., Wood, E. C., Middlebrook, A. M., Kolb, C. E., Baltensperger, U., and Worsnop, D. R.: Evolution of organic aerosols in the atmosphere, Science, 326, 1525-1529, doi:10.1126/science.1180353, 2009.

Kanakidou, M., Seinfeld, J. H., Pandis, S. N., Barnes, I., Dentener, F. J., Facchini, M. C., Van Dingenen, R., Ervens, B., Nenes, A., Nielsen, C. J., Swietlicki, E., Putaud, J. P., Balkanski, Y., Fuzzi, S., Horth, J., Moortgat, G. K., Winterhalter, R., Myhre, C. E. L., Tsigaridis, K., Vignati, E., Stephanou, E. G., and Wilson, J.: Organic aerosol and global climate modelling: a review, Atmos. Chem. Phys., 5, 1053-1123, doi:10.5194/acp-5-1053-2005, 2005.

Kautzman, K. E., Surratt, J. D., Chan, M. N., Chan, A. W. H., Hersey, S. P., Chhabra, P. S., Dalleska, N. F., Wennberg, P. O., Flagan, R. C., and Seinfeld, J. H.: Chemical composition of gasand aerosol-phase products from the photooxidation of naphthalene, J. Phys. Chem. A, 114, 913-934, doi:10.1021/jp908530s, 2010.

Kim, Y.: Modélisation de la qualité de l'air: Évaluation des paramétrisations chimiques et météorologiques, Ph.D. thesis, Université Paris-Est, 2011.

Kim, Y., Couvidat, F., Sartelet, K., and Seigneur, C.: Comparison of different gas-phase mechanisms and aerosol modules for simu- lating particulate matter formation, J. Air Waste Manage. Assoc, 61, 1218-1226, 2011.

Lee, J. Y. and Lane, D. A.: Unique products from the reaction of naphthalene with the hydroxyl radical, Atmos. Environ., 43, 4886-4893, doi:10.1016/j.atmosenv.2009.07.018, 2009.

Lee, J. Y. and Lane, D. A.: Formation of oxidized products from the reaction of gaseous phenanthrene with the $\mathrm{OH}$ radical in a reaction chamber, Atmos. Environ., 44, 2469-2477, doi:10.1016/j.atmosenv.2010.03.008, 2010.

Lim, B. Y. and Ziemann, P. J.: Chemistry of secondary organic aerosol formation from $\mathrm{OH}$ radical-initiated reactions of linear, branched and cyclic alkanes in the presence of $\mathrm{NO}_{\mathrm{x}}$, Aerosol. Sci. Technol., 43, 604-619, doi:10.1080/02786820902802567, 2009a.

Lim, B. Y. and Ziemann, P. J.: Effects of molecular structure on aerosol yields from $\mathrm{OH}$ radical-initiated reactions of linear, branched, and cyclic alkanes in the Presence of $\mathrm{NO}_{x}$, Environ. Sci. Technol., 43, 2328-2334, doi:10.1021/es803389s, 2009b.

Mallet, V., Quélo, D., Sportisse, B., Ahmed de Biasi, M., Debry, É., Korsakissok, I., Wu, L., Roustan, Y., Sartelet, K., Tombette, M., and Foudhil, H.: Technical Note: The air quality modeling system Polyphemus, Atmos. Chem. Phys., 7, 5479-5487, doi:10.5194/acp-7-5479-2007, 2007.

Menut, L., Goussebaile, A., Bessagnet, B., Khvorostiyanov, D., and Ung, A.: Impact of realistic hourly emissions profiles on air pollutants concentrations modelled with CHIMERE, Atmos. Environ., 49, 233-244, doi:10.1016/j.atmosenv.2011.11.057, 2012.

Murphy, B. N. and Pandis, S. N.: Simulating the formation of semivolatile primary and secondary organic aerosol in a regional chemical transport model, Environ. Sci. Technol., 43, 47224728, doi:10.1021/es803168a, 2009.

Nenes, A., Pandis, S., and Pilinis, C.: ISORROPIA: A new thermodynamic equilibrium model for multiphase multicomponent inorganic aerosols, Aquat. Geoch., 4, 123-152, 1998.

Offenberg, J. H., Lewandowski, M., Edney, E. O., Kleindienst, T. E., and Jaoui, M.: Investigation of a systematic offset in the measurement of organic carbon with a semicontinuous analyzer, J. Air Waste Manage. Assoc., 57, 596-599, 2007.

Pankow, J. F. and Asher, W. E.: SIMPOL.1: a simple group contribution method for predicting vapor pressures and enthalpies of vaporization of multifunctional organic compounds, Atmos. Chem. Phys., 8, 2773-2796, doi:10.5194/acp-8-27732008, 2008.

Peltier, R. E., Weber, R. J., and Sullivan, A. P.: Investigating a liquid-based method for online organic carbon detection in atmospheric particles, Aerosol. Sci. Technol., 41, 1117-1127, doi:10.1080/02786820701777465, 2007.

Polidori, A., Turpin, B., Lim, H.-J., Cabada, J. C., Subramanian, R., Pandis, S. N., and Robinson, A. L.: Local and regional secondary organic aerosol : Insights from a year of semi-continuous carbon measurements at Pittsburgh, Aerosol. Sci. Tech., 40, 861-872, doi:10.1080/02786820600754649, 2006.

Presto, A. A., Miracolo, M. A., Donahue, N. M., and Robinson, A. L.: Secondary organic aerosol formation from high- $\mathrm{NO}_{\mathrm{x}}$ photo-oxidation of low volatility precursors: n-Alkanes, Environ. Sci. Technol., 44, 2029-2034, doi:10.1021/es903712r, 2010.

Prevot, A. S. H., Crippa, M. Pandis, S., Beekmann, M., and Baltensperger, U.: Organic aerosols and their sources in Paris during the MEGAPOLI campaigns, Geophysical Research Abstracts, 
13, EGU2011-4631-2, 2011.

Pun, B.: Development and initial application of the sesquiversion of MADRID, J. Geophys. Res., 113, D12212, doi:10.1029/2008JD009888, 2008.

Pun, B., Griffin, R., Seigneur, C., and Seinfeld, J.: Secondary organic aerosol 2. Thermodynamic model for gas/particle partitioning of molecular constituents, J. Geophys. Res., 107, 433, doi:10.1029/2001JD000542, 2002.

Pun, B., Wu, S.-Y., Seigneur, C., Seinfeld, J., Griffin, R., and Pandis, S.: Uncertainties in modeling secondary organic aerosols: threedimensional modeling studies in Nashville/Western Tennessee, Environ. Sci. Technol., 37, 3647-3661, doi:10.1021/es0341541, 2003.

Pun, B., Seigneur, C., and Lohman, K.: Modeling secondary organic aerosol formation via multiphase partitioning with molecular data, Environ. Sci. Technol., 40, 4722-4731, doi:10.1021/es0522736, 2006.

Pye, H. O. T. and Seinfeld, J. H.: A global perspective on aerosol from low-volatility organic compounds, Atmos. Chem. Phys., 10, 4377-4401, doi:10.5194/acp-10-4377-2010, 2010.

Robinson, A. L., Donahue, N. M., Shrivastava, M. K., Weitkamp, E. A., Sage, A. M., Grieshop, A. P., Lane, T. E., Pierce, J. R., and Pandis, S. N.: Rethinking organic aerosols: semivolatile emissions and photochemical aging, Science, 315, 1259-1262, doi:10.1126/science.1133061, 2007.

Royer, P., Chazette, P., Sartelet, K., Zhang, Q. J., Beekmann, M., and Raut, J.-C.: Comparison of lidar-derived $\mathrm{PM}_{10}$ with regional modeling and ground-based observations in the frame of MEGAPOLI experiment, Atmos. Chem. Phys., 11, 1070510726, doi:10.5194/acp-11-10705-2011, 2011.

Russel, A. and Dennis, R.: NARSTO critical review of photochemical models and modeling, Atmo. Environ., 34, 2283-2324, doi:10.1016/S1352-2310(99)00468-9, 2000.

Russell, M. and Allen, D. T.: Predicting secondary organic aerosol formation rates in southeast Texas, J. Geophys. Res., 110, D07S17, doi:10.1029/2004JD004722, 2005.

Sartelet, K., Debry, E., Fahey, K., Roustan, Y., Tombette, M., and Sportisse, B.: Simulation of aerosols and gas-phase species over Europe with the Polyphemus system. Part I: model-todata comparison for 2001, Atmos. Environ., 41, 6116-6131, doi:10.1016/j.atmosenv.2007.04.024, 2007.

Sarwar, G., Luecken, D., Yarwood, G., Whitten, G. Z., and Carter, W. P. L.: Impact of an Updated Carbon Bond Mechanism on Predictions from the CMAQ Modeling System: Preliminary Assessment, J. Appl. Meteor. Climatol., 47, 3-14, doi:10.1175/2007JAMC1393.1, 2008.
Schauer, J. J., Kleeman, M. J., Cass, G. R., and Simoneit, B. R. T.: Measurement of emissions from air pollution sources. 2. $\mathrm{C}_{1}$ through $\mathrm{C}_{30}$ organic compounds from medium duty diesel trucks, Environ. Sci. Technol., 33, 1578-1587, doi:10.1021/es980081n, 1999.

Sciare, J., d'Argouges, O., Zhang, Q. J., Sarda-Estève, R., Gaimoz, C., Gros, V., Beekmann, M., and Sanchez, O.: Comparison between simulated and observed chemical composition of fine aerosols in Paris (France) during springtime: contribution of regional versus continental emissions, Atmos. Chem. Phys., 10, 11987-12004, doi:10.5194/acp-10-11987-2010, 2010.

Sciare, J., D’Argouges, O., Sarda-Estève, R., Gaimoz, C., Dolgorouky, C., Bonnaire, N., Favez, O., Bonsang, B., and Gros, V.: Large contribution of water-insoluble secondary organic aerosols in the region of Paris (France) during wintertime, J. Geophys. Res., 116, D22203, doi:10.1029/2011JD015756, 2011.

Shrivastava, M., Fast, J., Easter, R., Gustafson Jr., W. I., Zaveri, R. A., Jimenez, J. L., Saide, P., and Hodzic, A.: Modeling organic aerosols in a megacity: comparison of simple and complex representations of the volatility basis set approach, Atmos. Chem. Phys., 11, 6639-6662, doi:10.5194/acp-11-6639-2011, 2011.

Song, C., Zaveri, R. A., Alexander, M., Thornton, J. A., Madronich, S., Ortega, J. V., Zelenyuk, A., Yu, X.-Y., Laskin, A., and Maughan, D. A.: Effect of hydrophobic primary organic aerosols on secondary organic aerosol formation from ozonolysis of $\alpha$-pinene, Geophys. Res. Lett., 34, L20803, doi:10.1029/2007GL030720, 2007.

Tsimpidi, A. P., Karydis, V. A., Zavala, M., Lei, W., Bei, N., Molina, L., and Pandis, S. N.: Sources and production of organic aerosol in Mexico City: insights from the combination of a chemical transport model (PMCAMx-2008) and measurements during MILAGRO, Atmos. Chem. Phys., 11, 5153-5168, doi:10.5194/acp11-5153-2011, 2011.

Turpin, B. J. and Lim, H.-J.: Species contributions to $\mathrm{PM}_{2.5}$ mass concentrations: revisiting common assumptions for estimating organic mass, Aerosol. Sci. Tech., 35, 602-610, doi:10.1080/02786820119445, 2001.

Vestreng, V.: Review and revision. Emission data reported to CLRTAP Tech. Rep., EMEP MSW-W, Tech. rep., 2003.

Vutukuru, S., Griffin, R. J., and Dabdub, D.: Simulation and analysis of secondary organic aerosol dynamics in the South Coast Air Basin of California, J. Geophys. Res., 111, D10S12, doi:10.1029/2005JD006139, 2006.

Wang, L., Atkinson, R., and Arey, J.: Formation of 9,10phenanthrenequinone by atmospheric gas-phase reactions of phenanthrene, Atmos. Environ., 41, 2025-2035, doi:10.1016/j.atmosenv.2006.11.008, 2007. 